\title{
Ritmo e música no pensamento de poetas e filósofos: de Hölderlin a Rilke e Heidegger
}

\author{
Rhythm and Music in the contemplation of poets and philosophers: \\ from Hölderlin to Rilke and Heidegger
}

\section{Kathrin Rosenfield}

Universidade Federal do Rio Grande do Sul, Porto Alegre, RS, Brasil.

kathrinrosen@gmail.com

Resumo: Desde o pré-romantismo alemão, a música mantém relações cada vez mais íntimas com a poesia e a literatura. Rastreamos aqui alguns dos modos de aproximação destas duas formas diversas de expressão artística, mostrando como a literatura explora a alteridade da música para intensificar as dimensões afetivas e reflexivas da poesia. Trata-se de uma tradição poderosa que se estende de românticos como Hölderlin e Tieck até Rilke e além, ocupando um lugar de destaque no pensamento de Schopenhauer, Nietzsche, Heidegger. As reflexões de Rilke recebem um lugar de destaque neste artigo, mediante a tradução de suas anotações de leitura do famoso ensaio de Nietzsche, $O$ nascimento da tragédia a partir do espírito da música.

Palavras-chave:literatura e música; reflexão crítica e filosófica.

Abstract: Since German pre-romanticism, music has being keeping a closer relationship with poetry and literature. We have collected a few ways of approaching these two different forms of art expression, demonstrating how literature explores the alterity of music in order to intensify the affective and reflexive emotions of poetry. It deals with a powerful tradition that comprises 'romantic' authors from Hölderlin to Tieck to Rilke, and play an important role in the reasoning of Schopenhauer, Nietzsche and Heidegger. Rilke's reflections have been given special emphasis in this article, which is shown by means of his translated reading notes of the famous essay The Birth of Tragedy through the Spirit of Music.

Keywords: literature and music; critical and philosophical reflection.

Data de recebimento: 12/12/2015

Data de aprovação final: 15/04/2016 


\section{1- Introdução}

Na reflexão filosófica sobre a música desenham-se, entre o final do século XVIII e o início do XX, duas concepções que ora se opõem, ora se combinam: a música como princípio criativo que constitui a razão de ser da arte e sua inteligibilidade intrínseca (porém diversa do pensamento discursivo); e a musicalidade como força obscura, potencialmente irracional e pulsional (triebhaft, instintiva). Para compreender o interesse de artistas como Rilke pelas ideias de Nietzsche, será talvez interessante rastrear rapidamente as ideias relacionadas com o ritmo, a música e a Stimmung (tonalidade, atmosfera) que marcam os dois últimos séculos.

Schiller é provavelmente uma das fontes para todas as concepções posteriores que derivam da poesia da música. Deriva a inspiração poética de um "estado musical indeterminado" que precede qualquer imagem, representação ou ideia. A musicalidade é, assim, a matriz, o envelope que abriga, numa fusão perfeita, o Eu e o mundo. Na musicalidade superamos de modo ingênuo a clivagem cósmica que isola o indivíduo do todo do cosmos. A poesia moderna, entretanto, tornou-se consciente (demais) desta clivagem; para apagar esta tomada de consciência dolorosa manifesta na "natureza cósmica do grito de pavor" (isto é, no momento mítico de clivagem do Eu e do Todo natural, Allnatur des Schreckensschreies). Essa consciência dolorosa marca o surgimento do "sentimental" (que contrasta com o ingênuo) da poesia romanticmoderna, que reforça a expressividade sentimental da perda, o canto lutuoso (BOHRER, 1998, p. 141).

Hegel parece retomar e desdobrar esta visão quando concebe o ritmo e o "soar" (Tönen) são concebidos como o próprio movimento do espírito, como encarnação concreta da lógica e da verdade. Na Fenomenologia do Espírito, o filósofo usa uma inusitada metáfora que se refere à essência da verdade como ritmo delirante, «tontear (ou delírio) báquico ». Em outras palavras, Hegel aproxima a verdade lógica do processo (estético) de integração rítmica, que a mitologia atribui à potência do deus Dionysos ou Baco: 
ROSENFIELD, Kathrin (2016) Ritmo e música no pensamento de poetas e filósofos: de Hölderlin a Rilke e Heidegger. Per Musi. Ed. por Fausto Borém e Lia Tomás. Belo Horizonte: UFMG, n.35, p.15-45.

A aparição (Erscheinung) é o surgir e passar, o [processo] que ele mesmo não surge e passa, mas que é em si mesmo e constitui a efetividade e o movimento da vida da verdade. 0 verdadeiro é assim o delírio báquico no qual nenhum elemento-momento escapa à embriaguez (Hegel, 1970, Ph 3, 46, Hegel, 2002, FE 53).

A frase reitera a ideia, onipresente em toda a introdução, da « natureza líquida » que unifica os momentos distintos e sucessivos. A 'liquidez' reconduz o diverso para a unidade e, assim, constitui a necessidade lógica (atemporal); ao mesmo tempo, ela torna perceptível a unidade orgânica da coisa ela mesma no tempo. Em vários momentos, Hegel ilustra esta ideia com exemplos: o botão, a flor, a fruta e a semente se recalcam e excluem mutuamente ao longo do tempo, embora todas estas fases constituam, para « a vida do todo » momentos de « igual necessidade » (HEGEL, 1970 Ph 3, 12); outro exemplo é o do embrião, da criança recém-nascida e do homem racional como figuras que desenvolvem no tempo/espaço seu potencial, efetuando

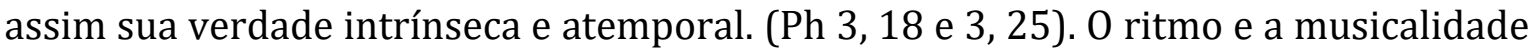
constituem, assim, a essência do espírito, o trabalho da negatividade (movimento puro) que medeia a passagem dos aspectos energéticos concretos, da violência cruel, para o reconhecimento do espírito que habita a própria concretude do mundo ${ }^{1}$.

Como Goethe, Hegel acentua a mediação e a conciliação apaziguadora do ritmo e da musicalidade, cuja qualidade matemática permite sintetizar as tensões entre determinações; pendor para des-sensualizar e espiritualizar a atividade artística; a música, com suas analogias matemáticas, presta-se particularmente bem para este fim. No mesmo sentido, Hegel refere-se também à pintura não representativa como música objetiva²: "puro soar em cores" (Tönen in Farben), pura transição, fusão, dissolver-se.

\footnotetext{
${ }^{1}$ Ritmo é a alteridade do Espírito diante dos conteúdos configurados em conceitos (ou figurações estéticas históricas). Necessidade lógica do ir-adiante do Espírito = concebida como ritmo: racional é o ritmo do todo orgânico, saber do conteúdo enquanto conceito e essência: figuração concreta movendose a si mesma (HEGEL, 1970, Ph 3, 55; FE 60); Cf. também a tensão entre o pensamento que desliza pelas representações VS o efeito da síntese reflexiva que ocorre com a interrupção de deslize destraído, o contragolpe do conceito (Ph 3, 57-58; FE 62-3)

2Cf. a expressão Hegeliana "ein Tönen in Farben": "soar [na sinfonia] das cores" nos confere a noção tangível da "transição pura" (purer Übergang) que permite apreender ao mesmo tempo as cores determinadas e distintas e o modo como se dissolvem num acorde (verschmelzen, auflösen) (HEGEL, 1970. Ae, 14, 228-30).
} 
ROSENFIELD, Kathrin (2016) Ritmo e música no pensamento de poetas e filósofos: de Hölderlin a Rilke e Heidegger. Per Musi. Ed. por Fausto Borém e Lia Tomás. Belo Horizonte: UFMG, n.35, p.15-45.

Schopenhauer insurge-se contra estas concepções racionais que espiritualizam o prazer estético. Ele descarta o caráter "desinteressado" do juízo estético de Kant e, mais ainda, a filosofia das mediações hegelianas que levam da certeza sensível, à consciência e à autoconsciência: isto é, a um reconhecimento reflexivo do indivíduo e do mundo. A ideia de um salto lógico (num conflito no qual um sujeito faz sua a lei e se torna livre), é para Schopenhauer um erro do idealismo. Em O Mundo como vontade e representação, ele concebe a individuação não como um processo que garante a liberdade, nem a autonomia do sujeito. Pois o principium individuationis é apenas um dos aspectos do princípio da razão suficiente. $\mathrm{Na}$ individuação, a autoconsciência acompanha os impulsos corporais e é inseparavelmente tingida por eles; ela não é uma instância autônoma. A capacidade de julgar e deliberar são inerentes aos modos de percepção3 .

Esta nova concepção que oscila entre uma dimensão materialista e uma mística, inserese na visão schopenhaueriana do corpo. Este é dado para nós de duas maneiras: de um lado, como objeto físico, e, tal como outros objetos materiais externos, sujeito às leis da física; de outro, através da nossa percepção imediata que surge do habitar consciente deste corpo, dos movimentos intencionais, da sensação de prazeres, dores e estados emocionais. No primeiro modo o nosso corpo existe para nós como representação isto é, externo, como objeto. No segundo ele se manifesta como vontade, movimento subjetivo, interno: Schopenhauer não separa o ato deliberado (a intenção de mover) do movimento físico. Ambos são unidos como os dois lados de uma moeda e, portanto, são inseparáveis. A ação do corpo é a objetivação, a encarnação da vontade. Em outras palavras, o homem não é mestre racional que reina sobre o corpo, mas a própria razão é como que uma rolha que flutua nos fluxos de um mar de forças obscuras.

Como transcender o mundo repleto de violência, feiura, destruição que resulta deste estar-e-ser-impulsionado? Schopenhauer reconhece (na experiência estética) uma possibilidade de ultrapassar a veemência da vontade que opõe os indivíduos e

\footnotetext{
${ }^{3}$ Schopenhauer vincula o principium individuationis com espaço e tempo, com a racionalidade e a necessidade, com sistemacidade e determinismo. Seus conceitos de princípio de razão suficiente e princípio de individuação comprimem todo o aparato conceitual de Kant: as formas puras do espaço e do tempo, e as doze categorias do entendimento (unidade, pluralidade, totalidade, realidade, negação limitação substância, causalidade, reciprocidade, possibilidade, atualidade, necessidade).
} 
ROSENFIELD, Kathrin (2016) Ritmo e música no pensamento de poetas e filósofos: de Hölderlin a Rilke e Heidegger. Per Musi. Ed. por Fausto Borém e Lia Tomás. Belo Horizonte: UFMG, n.35, p.15-45.

fragmenta o mundo em representações isoladas e hostis. A própria experiência interior viabiliza um recolhimento à contemplação do movimento que opõe os polos subjetivo e objetivo, e esta contemplação abre o "espaço" de um estado perceptivo que nos distancia do impulsivo ir adiante e que deixa aparecer uma ideia além da vontade e da dor ( $W W V$, \#34). Mas apenas o gênio artístico é capaz de permanecer no estado puro da percepção estética que se aproxima da visão das Ideias platônicas ( $W W V$, \# 50).

Schopenhauer estabelece a seguinte hierarquia das artes que culmina na poesia e na música: Arquitetura, escultura, pintura, poesia - a música transcende todas estas artes, pois nela, todas as formas são transitórias, puras relações que não se deixam captar de modo isolado e estático. Esta forma de expressão é diametralmente oposta à linguagem científica que fixa os objetos e os isola abstratamente segundo parâmetros arbitrários (medição, número, experimentos artificiais).

Na música a vontade transfigura-se em tensões que unem-ao-opor, que medeiam entre contrastes, que harmonizam mesmo quando usam dissonâncias. Música é, portanto, uma cópia purificada da própria vontade. Schopenhauer concebe a experiência estética como harmonização do sofrimento da individuação:

\footnotetext{
Esta encerra em si, do mesmo modo, objeto e sujeito, uma vez que estes são sua única forma: nela, contudo, ambos mantêm estritamente o equilíbrio: e como também aqui o objeto nada mais é do que a representação do sujeito, assim também o sujeito, dissolvendo-se por inteiro no objeto contemplado, passa a ser este objeto, na medida em que toda a consciência não é mais do que a sua imagem mais nítida (WWV, \# 34).
}

Este compartilhar fusional se expressa nas imagens do fluir, deslizar, pairar, envolver e entrelaçar. A música é a mais metafísica das artes, na escuta das harmonias entramos no mundo das formas platônicas, contemplamos símbolos das Ideias, pois as relações dos sons são como os modelos sublimes dos objetos do mundo.

Nietzsche segue Schopenhauer na oposição contra o vetor racional do pensamento hegeliano, sem perceber num primeiro momento quão próximo suas ideias permanecem da dialética hegeliana. Ele o reconhece apenas posteriormente, quando escreve o Tentame de autocrítica para a segunda edição de $O$ nascimento da tragédia 
do espírito da música. Na sua obra de juventude, ele procura pôr em evidência princípios derivados da observação empírica mais sóbria (e despojada dos pressupostos morais dos empiristas ingleses). Os princípios dionisíaco e apolíneo são concebidos como "pulsões" (Triebe) elementares. O Dionisíaco como potencial de força solta, comparável ao impacto vital e emocional da música nas suas manifestações espontâneas, populares. 0 Apolíneo como força antagônica, estabilização da energia na imagem. É nítida a oposição de Nietzsche aos estereótipos classicistas quando põe em relevo as marcas vitais e cruas do som puro da música popular ${ }^{4}$. Seja como for, o filósofo assinala uma espécie de degradé das dissonâncias paroxísticas do grito ritual nos sacrifícios primitivos (Sacéias de Zagreus na Frígia, por exemplo) para o refinamento rítmico, melódico e musical depurado do coro dionisíaco: o princípio dionisíaco, tal como se manifesta no coro trágico é considerado como uma forma avançada e complexa da arte. 0 equilíbrio formal é testemunho do trabalho de harmonização que a pulsão formal e o rigor do apolíneo imprimiram sobre os derramamentos embriagados do pulsar dionisíaco.

Mas já bem antes de Nietzsche e Schopenhauer surgiram, entre os poetas românticos alemães, alguns pensadores que enfatizaram o potencial estético-afetivo da música: sua capacidade de agir diretamente sobre a sensibilidade e a disposição não é propriamente irracional; ela antes constitui uma outra dimensão da vivência e da existência como um todo; nela se manifesta a presença de algo radicalmente Outro, que não pode ser subsumido ao entendimento, mas antes o envolve. Forma-se assim, em pleno idealismo e classicismo de Weimar (com suas preferências pela ponderação iluminista) uma contracorrente que acompanha como um som inquietante e ameaçador as teorias da mediação musical: o (pré)romantismo nas suas vertentes atmosférica e irônicas.

\footnotetext{
${ }^{4}$ Seria interessante desenvolver hipóteses em torno da ideia que Nietzsche se fazia da música popular. Pois as composições de sua autoria em nada lembram os festivais de recitação musical popular, tal como existem ainda hoje em Creta e cujas características se encaixam perfeitamente nas observações teóricas de Nietzsche.
} 
ROSENFIELD, Kathrin (2016) Ritmo e música no pensamento de poetas e filósofos: de Hölderlin a Rilke e Heidegger. Per Musi. Ed. por Fausto Borém e Lia Tomás. Belo Horizonte: UFMG, n.35, p.15-45.

A palavra Stimmung refere-se, em sentido filosófico, a um permanecer transfixo na mera possibilidade - encontro com uma dimensão de energias e emoções que nos ultrapassam, sensações, angústias que correspondem à manifestação de potências irredutíveis ao domínio psicológico; a Stimmung (atmosfera, tom) é a resposta imediata a uma alteridade extrema, potencialmente ameaçadora (o vago, outro anônimo, inominável), mas expõe-se a ele, desloca o centro da percepção da ação do $\mathrm{Eu}$ (falante e pensante) para o algo indeterminado (atmosfera outra).

Para e os românticos, o ritmo e a música situam-se numa dimensão da experiência além dos sentidos conceituais que se desenham com clareza na consciência, num horizonte no extremo limite da significação calculável - horizonte este, no qual a “consciência suspende a consciência”. (HÖLDERLIN, 1994, DKV 2, 917)

Já o pensamento de Hölderlin considerava o "ritmo", i. e, a peculiaridade do movimento da representação, como um procedimento outro e irredutível à lógica discursiva. A lógica poética distingue-se, assim, da firmeza do pensamento e do cálculo racionais. Inacessível à consciência e ao entendimento, a dimensão rítmica não é, entretanto, irracional no sentido psicológico do termo; apenas leva em consideração o imponderável das constelações muito complexas cujo horizonte será, evidentemente, a contingência, o acaso e o tempo sempre inconcluso. 0 Romantismo colocou o ritmo e a música no centro da reflexão estética. A música corresponde ao pensamento como forma peculiar da consciência (ela nega o pensamento de modo peculiar).

Um dos poemas de Tieck evoca o "pensamento" sui generis da música e da poesia: Em doces sons pensa o amor / Razão lhe causa estranheza / 0 tom prefere com certeza / Para o belo ficar melhor. ${ }^{5} \mathrm{Em}$ outras palavras, a musicalidade produz, tal como a fantasia romântica, o "maravilhoso extremo", o "infinito" (Hoffmann), e, com isto, a exploração de regiões particularmente suscetíveis de suscitar angústia e medo (Beethoven, Mozart), evocando ao mesmo tempo uma dimensão radicalmente outra -

5 Liebe denkt in süssen Tönen / Denn Gedanken stehn zu fern / Nur in Tönen mag sie gren / Alles was sie will verschönern (Tieck). 
ROSENFIELD, Kathrin (2016) Ritmo e música no pensamento de poetas e filósofos: de Hölderlin a Rilke e Heidegger. Per Musi. Ed. por Fausto Borém e Lia Tomás. Belo Horizonte: UFMG, n.35, p.15-45.

que se manifesta ora de modo angelical, ora no registro demoníaco (motivo que aparece também na novela de Kleist, Santa Cecilia ou o poder da música).

K.H. Bohrer recorda que o apego musical dos poetas românticos aos princípios do som e do ritmo levara Thomas Mann a formular a seguinte equação: a música se iguala ao romantismo como um todo - romantismo entendido como aquele movimento (tardio) de Beethoven a Wagner que começa a desenhar-se como ameaça para o humano normativo (BOHRER, 1998, p. 37-38). Se houver uma obra que sintetiza de maneira exemplar o intenso diálogo dos pensadores e poetas alemães com a (filosofia da) música, esta obra é, sem dúvida, Doutor Faustus de Thomas Mann. Escrito entre 1943 e 47, este romance alegoriza os efeitos ultimamente nocivos de uma tensão que se perfila desde o início do século XIX - a que opõe a fluidez dos estados sensíveis (musicais e rítmicos) à firmeza dos conceitos e juízos. Há dois personagens de caráter diametralmente oposto: Adrian Leverkühn, o músico que pactua com Mefistófeles para assegurar-se 25 anos de genialidade expressiva; e Serenus Zeitblom, o amigo-cronista pacato que narra a história do gênio comprometido com o mal como derradeira tentativa de criar uma mediação entre o inominável dos estados maravilhosos e angustiantes, de um lado, e a racionalidade humanista, do outro. 0 desejo sedento de mais criatividade e vida (sobrehumana e subumana) representam não somente o lado noturno e irracional do fascismo que pôs em xeque a razão iluminista, mas evocam também as principais posturas artísticas que se desenharam ao longo do século XIX e no século XX. Entre Beethoven e Wagner começa o culto da potência expressiva, cujo daimon encarna o desejo do infinito, absoluto, maravilhoso.

Este outro modo de ser, sentir e pensar - acessível somente através da atmosfera, coloração e tonalidade (Stimmung) - exerce uma influência decisiva também sobre Delacroix e Baudelaire, e, mais tarde, sobre as vanguardas do modernismo.

Não é a música como tal, mas a ritmicidade e a musicalidade da poesia - ou seja, a essência lírica - que fornece a base da reflexão filosófica sobre as relações de determinadas qualidades atmosféricas com o pensamento conceitual. Pela primeira 
ROSENFIELD, Kathrin (2016) Ritmo e música no pensamento de poetas e filósofos: de Hölderlin a Rilke e Heidegger. Per Musi. Ed. por Fausto Borém e Lia Tomás. Belo Horizonte: UFMG, n.35, p.15-45.

vez, concede-se um estatuto filosófico próprio aos sons, tons, timbres e ritmos que coloram os afetos sem serem psicológicos.

No século XX, esta qualidade atmosférica se transformará, na obra de Heidegger, na categoria ontológica da disposição. Heidegger eleva a Gestimmtheit (disposição, afinação) ao nível de uma categoria e transforma a essência do lirismo, a Stimmung romântica em categoria existencial. Ela expressa um modo específico da temporalidade do pavor (HEIDEGGER, Ser e Tempo, 2001, p.134-141, 182), dimensão existencial supra-pessoal que antecede a consciência e permanece clivada da tomada de consciência psicológica (BORHER, 2000, p. 55) .

Heidegger apoia seus conceitos nas constelações metafóricas "auráticas" de dois poetas (Hölderlin e Rilke) que estruturam a reflexão heideggeriana em conformidade às potencialidades expressivas da fala lírica:

0 estar contido, no meio-termo atmosférico entre medo e acanhamento, o traço fundamental da atmosfera fundamental: nele, o ser-aí se afina com a quietude do derradeiro deus que passa. Ao ser criativo nesta atmosfera fundamental do ser-aí, o homem se torna o guardião desta quietude. (HEIDEGGER, 1994, Bd. 65, S. 17).

\section{2- Rilke e o espírito nietzscheano da música:}

"A melodia como luz da poesia"

Na juventude de Rilke, descoberta e o estudo da obra de Nietzsche marcaram uma etapa decisiva no caminho deste poeta lírico que é, sem dúvida, um dos guardiões mais destacados da quietude. Na sua obra, temos acesso a uma evidência musical que os

${ }^{6} \mathrm{Cf}$. Tb. Sprachen der Ironie, Sprachen des Ernstes, “Die Heideggersche Reduktion und Vereinheitlichung von Hölderlins Sprache", p. 375 ss. 
ROSENFIELD, Kathrin (2016) Ritmo e música no pensamento de poetas e filósofos: de Hölderlin a Rilke e Heidegger. Per Musi. Ed. por Fausto Borém e Lia Tomás. Belo Horizonte: UFMG, n.35, p.15-45.

jogos de linguagem especulativos de Heidegger conjuram, sem, no entanto alcançar a intensidade expressiva do modo poético.

Rilke nasceu em 1875, um pouco cedo demais para ser um jovem modernista. Além disto, nasceu em Praga, num contexto familiar, social e geográfico burguês resistente à inovação e do qual ele se distanciou cedo. É bem conhecido que sua poesia suscitou algumas resistências entre modernistas avessos a anjos e ourivesarias poéticas, mas mesmo assim seus Dinggedichte exercem ainda hoje um impacto marcante sobre a poesia alemã, e, no Brasil, sobre os concretistas. 0 cuidado especial que Rilke dedica à forma e à superfície concretas das coisas manifesta-se, primeiro, na reflexão sobre música e filosofia, estende-se depois para a escultura e pintura, e recebe seu polimento definitivo graças às experiências pessoais de fracasso e sofrimento. Seus primeiros textos críticos já mostram afinidades com Nietzsche, por exemplo, quando aborda temas como "A melodia das coisas". Mais tarde, Rilke se inspira na profunda e prolongada contemplação de artistas plásticos - em particular em Rodin e Cézanne. A dedicação ao trabalho será para Rilke a grande lição de Rodin no caminho que leva das convenções cotidianas de volta para a concretude "coisal", isto é, à presença tangível das coisas na sua estranha singularidade material. Veremos também nos textos sobre Nietzsche que a força e a intensidade - não a representação de temas e motivos - estão no centro do interesse do poeta. Nietzsche elogiou a superficialidade dos poetas gregos como caminho mais direto para uma profundidade que supera a metafísica pomposa dos pensadores contemporâneos; de modo análogo, Rilke é atraído pela capacidadesingela e plana - do olhar de Cézanne, cujas visões dissolvem os temas e as técnicas convencionais. Com ele aprende a ver de novo - o simples estar-aí das coisas captadas num jogo de cores. 0 ser outro das coisas-cores - materiais-e-imateriais - exerce o efeito de uma revelação minimalista sobre o olhar à procura de sentido. Nunca fixar o sentido apenas, sempre retornar ao caminho de sua evocação - ao ritmo e a melodia trazendo à tona a revelação da simples coisidade: eis a experiência determinante para a poética de Rilke. Há os mais diversos nomes para esta música de fundo - entre eles "o excedente de Deus", isto é, a força criadora que ainda não se fixou em criações e fenômenos conhecidos. 0 paradoxo de forças que atravessam e ultrapassam a concretude dos objetos dados, seu potencial assustador e eufórico, fascina Rilke 
ROSENFIELD, Kathrin (2016) Ritmo e música no pensamento de poetas e filósofos: de Hölderlin a Rilke e Heidegger. Per Musi. Ed. por Fausto Borém e Lia Tomás. Belo Horizonte: UFMG, n.35, p.15-45.

também na leitura da obra de Nietzsche, em particular de $O$ Nascimento da tragédia, anotado por ele em 1900, aos 25 anos.

Estas anotações marginais são fragmentos de livre associação do leitor Rilke em torno do ensaio de juventude de Nietzsche. Mais pessoal que um resumo ou uma leitura comentada, elas fazem parte de uma série de textos que testemunham do impacto que Nietzsche deixou na sensibilidade e no pensamento do poeta quando jovem. 0 interesse pela nova filosofia pós-hegeliana foi despertado cedo. Em 1892, Rilke, então com 17 anos, recebeu do pai a edição das obras de Schopenhauer, o que indica que este autor já contava entre os pensadores aceitáveis até para a sensibilidade da burguesia. Estas leituras, sem dúvida, prepararam o caminho para a recepção maravilhada das obras de Nietzsche. Sentimos nos textos desta época um nítido entusiasmo com as posturas anticristãs do filósofo e afinidades ainda mais intensas com a veemência nietzscheana contra o espírito filisteu da sociabilidade burguesa. Estas simpatias juvenis levam Rilke a compor, no início de 1896, um pequeno conto intitulado $O$ Apóstolo ${ }^{7}$, testemunho das leituras precoces e "mal-digeridas" de Darwin e Nietzsche" (LEPPMANN apud KA, III, 809). O conto expõe a aversão ao sentimentalismo que os hábitos convencionais teceram ao redor do amor cristão. 0 personagem sombrio e misterioso do conto proclama um credo ao des-amor e recusa as fáceis mentiras da misericórdia que a sociedade usa como ornamentos e diversões, junto com o resto do aparato distinto: seus chás, pratas e joias, ricos tecidos de damasco e iguarias.

A sátira é, nas palavras do próprio autor, uma "profissão de fé [nietzscheana] em parte profundamente séria, em parte satírica" (KA, III, 809) e, também, uma versão precoce da concepção exigente do amor que Rilke elaborará ao longo da década seguinte, por exemplo, nos dois poemas a Don Juan (1907 e 1908).

Uma resenha da época aponta que neste conto “[... as doutrinas de Nietzsche são demonstradas com nitidez gritante, e servidas em pratos cheios. É obrigatório ler

${ }^{7}$ Redigido em Praga 1896 (KA III, 47-52). 
aquilo para sentirmos a confusão do Übermensch nietzscheano". 80 próprio Rilke reconheceu mais tarde que várias de suas obras precoces adotaram de Nietzsche um "espírito anti-cristão excessivamente irado" (eine beinah rabiate Antichristlichkeit)9; assim, como por exemplo, nos poemas Glaubensbekenntnis (profissão de fé), Christus am Kreuz (Cristo na cruz), Christus-Visionen (Visões de Cristo) ou Der Brief des jungen Arbeiters (Carta de um jovem operário) ${ }^{10}$.

Em comparação com estas obras precoces, as anotações sobre O Nascimento da Tragédia, que aqui apresentamos em tradução comentada, são mais maduras e refletidas. Elas permitem entrever as convicções pessoais mais profundas e duradouras do poeta. 0 impulso para um estudo sistemático da obra de Nietzsche veio de Lou Andreas-Salome, amiga pessoal do filósofo que redigiu vários ensaios sobre sua obra. Ela desempenhou o papel de uma verdadeira mentora e tutora para Rilke, introduzindo-o na cultura de seu país de origem, a Rússia e viabilizando o acesso do jovem poeta a círculos psicanalíticos e filosóficos da época. A breve relação amorosa e o subsequente afastamento de Lou transformou-se numa produtiva "educação sentimental" que fortaleceu a vocação de Rilke pela poesia voltada para estados de abertura e visão que metamorfoseiam o estado amoroso.

O que conta na visão reveladora é a estranha concretude da evanescência, a coisa que se subtrai como objeto, que é de um modo que os nomes e as representações captam inadequadamente. É esta postura que confere sua aura tragicamente angelical à obra de Rilke: a música do permanente devir-no-desvanecer manifesta-se com particular nitidez na obra tardia (Elegias de Duíno), nas quais se desvelam as afinidades rilkeanas com a poética de Hölderlin, cujas ideias sobre ritmo e lógica poética antecipam o "espírito da música" de Nietzsche e o "ritmo de fundo" de Rilke.

\footnotetext{
${ }^{8}$ Cf. os trechos da resenha de Leppmann (in: Musen, Heft 6, maio-junho 1896), reproduzidos no comentário da edição crítica (KA, III, 809).

${ }^{9}$ Trecho da carta a Marie Von Thurn und Taxis, 17 dezembro, 1912, (KA, III, 809).

${ }^{10}$ Nenhum destes poemas foi traduzido para o português.
} 
No Brasil, o lirismo trágico de Rilke teve enorme impacto sobre Guimarães Rosa, cuja procura de Sachlichkeit concreta e de elevação elegíaca ou "hímnica" (de hino, ditirambo) manifesta-se na estrutura rítmica e musical de Grande Sertão: Veredas. Embora a poesia de Rilke possa parecer alheia às rudes polémicas de Nietzsche ou as travessias rosianas, os três autores compartilham a mesma dedicação poética à essência trágica e à "matéria vertente". Mas a descoberta desta afinidade do "Mestre seráfico" com os poetas-pensadores trágicos requer uma leitura mais aprofundada. Assim, não é de se surpreender que a poesia de Rilke já foi associada com "bijus de um níquel". Ninguém menos que Décio Pignatari, na Bufoneria Brasiliensis 1 - O Poeta Virgem, pronunciou este veredicto. Tampouco é difícil compreender porque modernistas e concretistas mais sóbrios repudiaram os afãs erótico-marciais do Corneto e as celebrações órficas dos Sonetos a Orfeu. Mas este repúdio talvez esteja mais um rechaço da enfática recepção brasileira dos anos 1940 e 50, que participou do "misticismo de fachada" do qual Paul de Man distanciou o poeta na sua introdução às obras de Rilke na França (MAN, 1972). Logo em seguida, entretanto, os concretistas superam sua aversão da "intensa voga de rilkeanismo" (CAMPOS, 2001; SARAIVA, 1984) e o desdém de poetas como Neruda (que esnobou "rilkistas, misterizantes, falsos brujos existenciales" no seu Canto General, V, Los Poetas Celestes, 1950). Haroldo e Augusto de Campos ${ }^{11}$ simplesmente deixaram de lado o culto messiânico que alguns prestaram a Rilke e debruçaram-se sobre o que importa - a atualidade dos Novos Poemas, dos poemas-coisa (Dinggedichte) e as Elegias de Duíno.

\section{3- Rilke: um dos mestres da "vida trágica e suspensa"}

Embora Rilke tenha percorrido todas as fases típicas do fin de sciècle, ele não pode ser identificado com nenhuma delas - nem com o credo naturalista, darwiniano e ateu, com seus bons sentimentos pelo povo (das einfache Volk), por trabalhadores e prostitutas; nem com o esteticismo decadentista com seus pendores por um vago misticismo e

11Ver: CAMPOS, H. Poesia de Vanguarda Alemã e Brasileira, In: A arte no horizonte do provável, São Paulo, Perspectiva, 1969. 
ROSENFIELD, Kathrin (2016) Ritmo e música no pensamento de poetas e filósofos: de Hölderlin a Rilke e Heidegger. Per Musi. Ed. por Fausto Borém e Lia Tomás. Belo Horizonte: UFMG, n.35, p.15-45.

doutrinas esotéricas, cujos livros de cabeceira eram Schopenhauer, Wilde ou D’Annunzio; e tampouco com o vigor nietzscheano do Zarathustra, nem com a fé panteísta dos que confiam na natureza, na transcendência dos movimentos cósmicos e na expressão corporal de artistas como Isadora Duncan.

Afinado com o trágico verter das coisas, com a fluidez das configurações momentâneas de todos os sentimentos, reflexões e atos, Rilke se destaca pela posição aquém e além dos movimentos do seu tempo. 0 fascínio juvenil pelo ateísmo quase religioso de Nietzsche, a delicadeza refinada de sua violência e a sutileza criteriosa (quase coreográfica) de seu iconoclasmo certamente consolidou sua dedicação ao trabalho de dissolver as imagens em novas constelações melódicas e rítmicas.

As anotações são um estudo intuitivo e associativo do texto de Nietzsche que procura fortalecer a poética do jovem poeta, não uma publicação. Rilke usava a edição Friedrich Nietzsche, Die Geburt der Tragögie. Oder: Griechenthum und Pessimismus. Neue Ausgabe mit dem Versucheiner Selbstkritik. Leipzig, Verlag von E. W. Fritzsch, 1889. 0 manuscrito encontrava-se entre os papeis de Lou Andreas-Salomé, que estimulou o interesse de Rilke em Nietzsche e Freud.

\section{4- Pequeno parêntesis: a influência de Schopenhauer e a superação do sofrimento e da solidão}

As leituras de Schopenhauer e de Nietzsche fazem, portanto, parte do cerne do desenvolvimento poético e existencial de Rilke. Ao ler Schopenhauer em 1892 (a obra completa foi presente do pai), ele se debate com o conflito seminal de sua vida e de sua futura poética - as tensões que não somente separam, mas unem dor e prazer, a arte e a vida. A arte é para Rilke harmonia paralela à natureza, pois as próprias coisas determinam as ordens estéticas como imagens puras das relações entre as forças da 
vida. É desta concepção que decorrem também as reservas de Rilke com relação ao expressionismo, quando este celebra a capacidade criativa de um sujeito que se coloca acima da relação com os objetos. A familiaridade com Schopenhauer e Nietzsche permitirão compreender melhor a relação de Rilke com as "coisas" enquanto mediadores das relações puras - visão de um Ur-Phänomen- isto é, da ideia vista através e para além da vontade e da dor $(W W W V$, \#34).

Há, porém, um aspecto da filosofia schopenhaueriana que Rilke rejeita de imediato: a ideia de que a conciliação definitiva do sofrimento possa ocorrer somente no domínio da moral, através da renúncia. Seguindo Nietzsche, ele se revolta contra a ideia schopenhaueriana da grande arte como renúncia ao feixe de pulsões difusas que impulsionam a "vontade". Arte não é, para ele, superação da vontade nem da vida, mas retração num espaço que favorece as forças criativas da vida e abre um novo acesso às coisas concretas: é uma solidão no cerne da vida concreta que protege o artista da dispersão ameaçadora; pois viver no mundo implica numa perda das forças artísticas e na acomodação nas convenções. A familiaridade excessiva dispersa a força rítmica, fixa a melodia como tema compreensível, ordena e classifica motivos, domesticando o que há de ameaçador e estranhos neles em vez de dissolver as tensões.

Certos temas e ideias "nietzscheanos" afloram já nas "Anotações sobre a melodia das coisas" (cf. Anexo, no final deste texto). Comparando a pintura dos "primitivos" italianos (figuras de santos cujas cabeças aparecem isoladas por auréolas douradas) com os mestres do chiaroscuro, Rilke destaca os efeitos poéticos "musicais" da combinação do desenho com as tonalidades da cor, de sombra e luz. É como se Rilke falasse, com outros termos e palavras, da tensão entre o princípio apolíneo (clareza nítida, compreensível e definida) e o dionisíaco (o fluido epifânico do ritmo e da melodia para além das notas), de forças que estão a trás das coisas representadas, as atravessam e envolvem. Estas forças - musicais, rítmicas ou dionisíacas, como Nietzsche os chamará - representam o princípio de unificação e de vitalidade que 
ROSENFIELD, Kathrin (2016) Ritmo e música no pensamento de poetas e filósofos: de Hölderlin a Rilke e Heidegger. Per Musi. Ed. por Fausto Borém e Lia Tomás. Belo Horizonte: UFMG, n.35, p.15-45.

reanima o que foi violentamente separado e isolado. Nas "Marginália" podemos destacar os seguintes tópicos como núcleos da leitura rilkeana de Nietzsche:

- música como energia cósmica precisa ser contida nas "vasilhas" do canto popular;

- a música entendida como "grande ritmo de fundo" é o "livre excedente de Deus", isto é, uma força ainda não ligada que sobrou da criação;

- ritmo e música constituem o potencial criativo;

- música como potência unificadora e promessa comunitária;

- música como força à espera da imagem;

- música como potência fusional é promessa de liberação das formas e convenções petrificadas;

- a melodia transfigura e torna dispensável o enredo (história racional);

- a música como força originária não pode ser instrumentalizada como decoração;

- o espírito da música como alma da integridade (social, política e pessoal) grega;

- música é fluxo ilimitado;

- a criação artística (canto, imagem, drama, escultura) são esforços de captar o excesso musical.

\section{5- Anexo1- Rainer Maria Rilke: "Marginalia em torno de Friedrich Nietzsche: 'O Nascimento da Tragédia', 1900”' 12}

Do seu interior, a melodia dá à luz a poesia, e isto sempre de novo; a forma estrófica da canção popular nos diz isto, e nada mais: observei este fenômeno sempre com espanto, até finalmente encontrar a presente explicação.

12 Tradução de Kathrin Rosenfield. 
ROSENFIELD, Kathrin (2016) Ritmo e música no pensamento de poetas e filósofos: de Hölderlin a Rilke e Heidegger. Per Musi. Ed. por Fausto Borém e Lia Tomás. Belo Horizonte: UFMG, n.35, p.15-45.

As estrofes da canção popular ${ }^{13}$ podem ser comparadas com vasilhas recebendo a água de uma fonte que jorra clara. Rica e rápida ela enche as primeiras vasilhas festivas que lhe foram preparadas. Mas elas não estancam seu jorro. E o povo termina por trazer todas as vasilhas de seu uso cotidiano e deixa a água enchê-las até ficarem pesadas. E as crianças estendem as mãos em conchas.

A música (o grande ritmo de fundo) deveria, portanto, ser compreendida como: a força intata que flui livre e que nos inspira certo pavor quando percebemos que ela não entra nas nossas obras para vir a conhecer-se no fenômeno, mas que paira por cima de nossas cabeças, despreocupada e alheia, como se nós não existíssemos. Como não somos capazes, porém, de suportar a força intata (i.e. o próprio Deus), estabelecemos relações com imagens, destinos e figuras e colocamos no seu caminho sempre mais coisas que a comparam com algo ${ }^{14}$, pois ela mesma passa, orgulhosa como um vitorioso, ao largo de todos os fenômenos.

A infinita liberdade de Deus foi limitada pela criação. Com cada coisa um pedaço de sua força ficou vinculado. Mas não é sua vontade toda que se encontra vinculada na criação. A música (ritmo) é o livre excedente de Deus, que não se esgotou ainda nos fenômenos, e este ritmo é o desafio dos artistas quando sentem a urgência indistinta, a posteriori,

\footnotetext{
${ }^{13}$ Rilke reage à ideia inovadora de Nietzsche que realçou o vigor dos elementos populares na tragédia. No entender de Nietzsche, as formas petrificadas da poesia erudita tornam-se flexíveis ao abrir-se às formas de expressão espontâneas e emocionalmente carregadas. É a atmosfera ou, como diz Rilke, a tela de fundo rítmica que dá acesso ao que há de sofrido, cruel, grotesco na experiência (heroica). Esta "música" da vida que se expressa para além do conhecido da forma clássica e da elegância artística formalmente acabada. A tragédia clássica não é para Nietzsche, o fim de um processo de refinamento linear, mas uma criação oriunda de uma ruptura com convenções cristalizadas, que abre espaço à irrupção de elementos heterogêneos da cultura popular (mitos arcaicos e cortejos rituais com sua ritmicidade e gestualidade próprias). Uma afinidade natural com as ideias de Nietzsche já se mostra no fato que as primeiras obras de Rilke, por exemplo, Larenopfer (Sacrifícios aos deuses do lar, 1895) partem das canções populares tchecas. Um dos poemas mais precoces, Volksweise, evoca a emoção e a intensidade da alma nas canções do povo da Boémia.

${ }^{14} \mathrm{~A}$ concepção vitalística da música (como força, ritmo, movimento elementar) que simultaneamente sustenta e ameaça a existência do indivíduo e da sociedade carrega o eco dos terrores da infância do poeta (muito semelhantes ao personagem Marcel de Proust). Para ambos, escrever é uma forma (existencial e terapêutica) de fazer face à memória involuntária na qual se entretecem reminiscências pavorosas e maravilhosas. Criar imagens é dar forma e manter em limites suportáveis este fundo inquietante. A incapacidade de abranger a pletora da força criativa (musical e rítmica) é um dos motivos de fundo do Stundenbuch (Livro das Horas), cuja primeira parte surgiu em 1899. 0 volume se apresenta como um constante jorro de imagens - verdadeira maré que a criatividade precisa estancar com incessantes perífrases, comparações.
} 
ROSENFIELD, Kathrin (2016) Ritmo e música no pensamento de poetas e filósofos: de Hölderlin a Rilke e Heidegger. Per Musi. Ed. por Fausto Borém e Lia Tomás. Belo Horizonte: UFMG, n.35, p.15-45.

de completar o mundo naquele sentido que esta força criaria ao prolongar sua criação - e esta criação erigiria imagens de realidades que ainda aguardam a irrupção. ${ }^{15}$

O Coro: para compreender corretamente a significação do sonho é necessário que vejamos o sonhador. Nossa participação se intensifica quando não é um ser humano, um ente apenas, mas vários que se sentem ritmicamente movidos pelo compartilhamento de seu sonho; eles então ocasionam aqueles fenômenos que são representados como ocorrendo fora de seus sentidos, como ação num palco, tal qual se desenrolam no interior [dos sonhadores] . Estes sonhadores são ao mesmo tempo capazes de nos livrar do medo e dos constrangimentos da ação, pois eles permanecem sempre iguais a si mesmos. Para compartilhar, no entanto, seu ser intocável, o qual não deve ser triturado pela crueldade de seus sonhos, é necessário que eles sejam parecidos conosco, fraternos, não nas coisas contingentes, mas no que toca os traços permanentes de nosso ser. Nós nos salvamos do jogo movimentado do palco tomando refúgio nos círculos calmos de sua dança, e sua segurança e proximidade nos devolvem a aptidão de nos alegrarmos com o pavoroso enquanto algo passageiro; desejamos até mesmo a catástrofe, para mirarmos, através da queda, o eterno que anima o coro.

Tal como a cultura grega se desenvolveu através do olho, a nossa amadurece pelo sentimento. Onde eles criaram, com o drama, um porto seguro e um refúgio para o olho, nós temos que auxiliar o sentimento. Se a tragédia ática exigia um coro visível, nós temos que tentar de construir o drama moderno a partir de um coro sensível ${ }^{16}$, e vê-lo através deste.

\footnotetext{
${ }^{15}$ Cf. Im Gespräch 1898/9 “Arte significa, não saber que o mundo já está aí e fazer um novo mundo [...] Nunca acabar. Nunca ter um sétimo dia. Nunca ver que tudo é bom [...] Eis minha razão contra ele (i.é Deus) [...] Pois ele não foi artista, e isto é tão triste [...], deveríamos recomeçar no lugar onde Deus parou [...]. Na vida isto significa, com o homem." (KA , IV, 838)

${ }^{16} \mathrm{Cf}$. "Sobre a Melodia das coisas", um conjunto de anotações nas quais Rilke fixa suas ideias sobre o fundo inacessível da vida, do mundo e das coisas. A tarefa do artista é precisamente esta abertura que permite o confronto com a "tela de fundo rítmica" (rythmischer Hintergrund). Na leitura do Nascimento da Tragédia, Rilke associa sua ideia do "fundo rítimico" com a dança rítmica e musical "do coro da antiguidade que absorveu a sabedoria mais sábia (das weisere Wissen)". Esta sabedoria criatural, arcaica, imemorial - que Nietzsche atribuía ao velho Sileno - está voltada para "aquilo que une" os homens "nas coisas à trás deles" (KA, IV, 103-113), em oposição ao valor semântico ou intelectual que confere domínio sobre o mundo.
} 
ROSENFIELD, Kathrin (2016) Ritmo e música no pensamento de poetas e filósofos: de Hölderlin a Rilke e Heidegger. Per Musi. Ed. por Fausto Borém e Lia Tomás. Belo Horizonte: UFMG, n.35, p.15-45.

O deleite do estado dionisíaco com sua aniquilação das fronteiras comuns da existência contém, enquanto dura, um elemento letárgico no qual mergulha tudo que foi vivido pessoalmente no passado. Assim há um abismo do esquecimento que separa o mundo cotidiano do dionisíaco.

A vida dionisíaca é um viver-em-tudo ${ }^{17}$ ilimitado, e em comparação a ela as coisas cotidianas são como uma mascarada ridícula. Mas a arte medeia a experiência de que esta mascarada é a única possibilidade de entrar, ora e vez, nestas conexões imensas que se estendem para além de momentos e metamorfoses.

Um público de espectadores tal como nós o conhecemos era impensável para os gregos: nos seus teatros cada um [...] era capaz de ver e dominar o universo cultural completo ao seu redor e, nesta visão saciada, podia identificar-se com os membros do coro; [o espectador] sentia que era, ele mesmo, um deles.

Como não é possível colocar diante de um grupo de seres humanos uma realidade que cada um possa sentir e compreender do mesmo modo, é preciso interpor entre o público e a cena um olho cujo olhar tranquilo percebe a ação a cada momento como correta e verdadeira ${ }^{18}$. E o público precisa corrigir sua compreensão a partir deste olho e tornarse, graças a ele, um só corpo imenso, que toma uma posição uniforme com relação aos acontecimentos no palco.

\footnotetext{
${ }^{17} \mathrm{Cf}$. as ideias análogas a este desejo de viver-em-tudo, que encontramos quase um século antes na identificação de Hölderlin com seu personagem trágico Empédocles: “Empédocles, [...] inimigo mortal de toda existência unilateral e, por isto, insatisfeito também quando vive em circunstâncias realmente belas, [e um ser] inconstante, sofrido, simplesmente porque não suporta o que há de específico e determinado nas circunstâncias e relações; apenas o que foi sentido num grande e amplo acordo com todos os viventes pode preenchê-lo plenamente; ele sofre simplesmente porque não consegue viver e amar com eles com um coração onipresente e intenso como um deus, e livre e espraiado como um deus, simplesmente porque ele está, assim que seu coração e seu pensamento apreendem as coisas existentes, acorrentado à lei da sucessão" (DKV, 2, 421).

${ }^{18} \mathrm{~A}$ música e a dança do coro são uma herança dos cortejos dionisíacos rituais arcaicos. Na tragédia a música assegura a participação imediata do espectador, que está presente em corpo-e-alma. Ela não apenas contagia, mas dá acesso também ao processo poético ocorrendo entre as linhas do texto, atrás das palavras e no fundo rítmico das coisas. Estas ideias têm grande afinidade com a ideia de Hölderlin à propósito da afinidade entre 'lógica poética' e o ritmo: o equilíbrio rítmico da apresentação da peça como um todo suspende o valor convencional (semantismo estático) das representações sucessivas. (DKV, 2, p. 849)
} 
ROSENFIELD, Kathrin (2016) Ritmo e música no pensamento de poetas e filósofos: de Hölderlin a Rilke e Heidegger. Per Musi. Ed. por Fausto Borém e Lia Tomás. Belo Horizonte: UFMG, n.35, p.15-45.

O coro de sátiros é, num primeiro momento, uma visão da massa dionisíaca, tal como por sua vez o mundo do palco é uma visão deste coro de sátiros: a força desta visão tem o poder de nos tornar insensíveis às impressões da 'realidade', tornando-nos indiferentes para com o olhar dos homens cultivados que ocupam os gradientes do anfiteatro.

No coro, o espectador reconhece-se a si mesmo, liberado de tudo que lhe é contingente e temporal (seinem Zufälligen und Zeitlichen), de sua cultura, e ele compreende, por este desvio, a visão daquele coro que se apresenta na ação, ele a compreende e ao mesmo tempo supera seu peso.

Agora o coro ditirâmbico recebe a tarefa de estimular a disposição dos espectadores até aquele grau do dionisíaco que lhes permite ver, quando o herói trágico entra em cena, não mais a máscara deformada do ser humano, mas uma visão encarnada (Visionsgestalt) nascida, por assim dizer, de seu próprio encantamento.

Não seriam as danças e canções dos povos selvagens ditirambos congelados neste ponto de vista preparatório, [ditirambos] que não conseguiram chegar ao amadurecimento no drama?

O magnífico 'saber fazer' do grande gênio, o qual não recebe sua paga nem mesmo através do sofrimento eterno, o orgulho amargo do artista - eis o conteúdo e a alma da poesia de Ésquilo, enquanto Sófocles com seu Édipo entoou o prelúdio do canto vitorioso do santo.

0 ato criador do artista tem algo equivalente somente no ocaso sofrido do não-artista: ambos ocasionam uma violência imensa nos seres melancólicos (schwersinnig). Por sobre o túmulo de um santo, despertam homens novos em número igual aos que acordam sobre a obra imortal de um artista criativo (ein Schaffender).

É preciso colocar no palco aquela ação que permita estimular no sentimento de cada indivíduo uma experiência viável e que aja com a potência violenta de uma imensa mão, 
ROSENFIELD, Kathrin (2016) Ritmo e música no pensamento de poetas e filósofos: de Hölderlin a Rilke e Heidegger. Per Musi. Ed. por Fausto Borém e Lia Tomás. Belo Horizonte: UFMG, n.35, p.15-45.

arrastando e unindo a massa dos espectadores ${ }^{19}$. 0 evento estimulador deve ocorrer de forma independente do status das figuras representadas, do seu meio e do tempo da ação, num segundo palco ideal, que se apresenta como o cenário daquele reencontro celebrado pelas almas liberadas dos espectadores que criaram afinidades nesta intensificação. A ação deve ocupar o segundo lugar que lhe cabe também no drama (de modo análogo ao que acontece na pintura), dando lugar a um acontecimento realmente artístico. 0 palco não deve tornar-se mais real, próxima da verdade, mas precisa ter mais afinidades com a aparência e a beleza. Algo comum aos homens (não aos homens de uma classe, de um tempo, de uma moral), mas aos homens como tais, precisa surgir por detrás da ação, como se fosse uma lembrança que une e que convoca todos a lembrarem-se e a refletirem sobre a infância que têm em comum; é neste ponto, não no âmbito do cenário e do enredo relativamente contingentes, que deve acontecer o que importa e o que redime. Não o jogo, mas a melodia do jogo ${ }^{20}$ deve ser a força sintética unificadora (das Zusammenfassende), pois cada um se encontrará em acontecimentos e experiências que seguiram o ritmo justamente desta melodia, (para a qual a peça é somente uma entre mil interpretações). (0 renascimento de Dionisos. [Nietzsche, cap. 8])

Depois do crepúsculo no qual findou a noite titanesca sempre pronta para a luta, levantou-se a manhã de Homero, que deu limites divinas às coisas. E seu sol estendeu sua alegria sublime sobre o rosto das coisas. Mas toda esta ordem parecia ter sido criada como uma bela paisagem para a tempestade dionisíaca poder passar.

É de se pensar que a rapidez colossal com que se produzem os progressos interiores em Sócrates, tornou ultrapassadas todas as possibilidades do pensamento, também aquelas que poderiam ter surgido de seu inconsciente; assim, o instinto empobrecido

\footnotetext{
${ }^{19}$ Segundo o editor da edição comentada (KA , IV, 839), Rilke projeta aqui umas nas outras as idéias de Maeterlinck e de Nietzsche. Numa carta à atriz Else Vonhoff, do 10 de dezembro de 1901 (KA, IV, 1909), ele escreve: "Maeterlinck [...] procura localizar [como fundamento] algum sentimento elementar [...] algo simples, próximo de um axioma e que se adéqüe à dimensão da canção popular, suas nostalgias e medos, sua crença... ele procura uma das grandes atmosferas de fundo sobre as quais repousariam, como que em pilares, os múltiplos e confusos corredores do labirinto das emoções humanas (Empfindungen)" (193).

${ }^{20} \mathrm{Cf}$. Anotações para a melodia das coisas, em particular a introdução (KA, IV, 103-113)
} 
ROSENFIELD, Kathrin (2016) Ritmo e música no pensamento de poetas e filósofos: de Hölderlin a Rilke e Heidegger. Per Musi. Ed. por Fausto Borém e Lia Tomás. Belo Horizonte: UFMG, n.35, p.15-45.

ficou de mãos vazias e pode defender-se apenas ao dar sinais de alerta e impedimento. Não seria o inconsciente sempre condenado a este papel quando se trata de cabeças logicamente muito ativas e talentosas? Somente na prisão (que acontece depois da eliminação de sua personalidade das posições de liderança na vida pública), quando a força lógica ficou ociosa, este instinto manifestou-se timidamente, ressoando como uma nostalgia no silêncio que precedeu a morte. Sua alma ansiava por música. E os lábios ressequidos no vento do verbo beberam intuições no cálice dos sons. E, talvez, não fora das coisas passadas que ele tirou a força para morrer, talvez não fora de sua obra, mas justo daquela nova promessa; assim ele foi para a morte como se fosse para o dia seguinte, sentindo que este seria o dia da música ${ }^{21}$.

Acreditamos na 'vida eterna', eis o que exclama a tragédia; enquanto a música é a ideia imediata desta vida. É totalmente diverso o alvo na arte do escultor: aqui Apolo supera o sofrimento do indivíduo através da glorificação esplendorosa da eternidade da aparência, aqui a beleza é vitoriosa sobre o sofrimento inerente à vida, a dor é por assim negada e borrada dos traços da natureza.

Com relação ao pretexto que usamos para aplicar a grande música dionisíaca ao caso particular enquanto imagem e parábola desta, poderíamos dizer que há pretextos mais e menos significativos e que o mais agudo é o mito ele mesmo, em particular o mito trágico. 0 trágico não se deixa de modo algum deduzir da arte enquanto bela aparência, apenas a música permite compreender a alegria para com a destruição do indivíduo. "Acreditamos na vida eterna", grita a tragédia, enquanto a música é a ideia mais imediata da vida.

\footnotetext{
${ }^{21}$ Fusão das ideias nietzschianas com a ideia freudiana do inconsciente. Onde a teoria de Freud ensina que o recalque e a censura não alteram a força da pulsão, porém (ao represar a pulsão) terminam por prejudicar a própria racionalidade (introduzindo atos falhos, lapsos, e formações neuróticas), Rilke identifica o inconsciente e o instinto como forças empobrecidas e debilitadas pela razão. Mas a força racional e lógica é prejudicial somente na sua forma aplicada à preceitos e convenções sociais, não em si mesma contrária ao instinto. Nesta fase de sua obra, Rilke acredita que, uma vez superados os imperativos da vida social, a força lógica abrir-se-ia de novo à plenitude e intensidade do dionisíaco, do instinto e do inconsciente.
} 
ROSENFIELD, Kathrin (2016) Ritmo e música no pensamento de poetas e filósofos: de Hölderlin a Rilke e Heidegger. Per Musi. Ed. por Fausto Borém e Lia Tomás. Belo Horizonte: UFMG, n.35, p.15-45.

Nas artes plásticas, Apolo supera o sofrimento do individuo através da glorificação da eternidade do fenômeno, enquanto a arte dionisíaca celebra literalmente a fuga eterna das imagens, dos fenômenos e aparências (Erscheinungen).

O mesmo abuso que sofre a música quando ela é forçada a colorar a posteriori um fenômeno (clamor da batalha, p.ex.) podemos encontrar também na lírica, - apenas quando entendemos música aqui (como já tentei fazê-lo antes) no sentido daquele ritmo primário do fundo, cujo saber ouvir inicia a criação lírica que se alimenta de sua redenção nas imagens que surgem. A maioria dos poemas não são imagens arrancadas ao frêmito da música estranha e intocada que jorra e flui, elas não giram como rodas de moinho na correnteza da água que cai, mas são como moinhos para os quais uma imensa labuta terá de levar águas longínquas e sonolentas a mover a roda com impulsos relutantes e vagarosos. Nos tempos em que os ritmos saltam e esguicham (rauschend ${ }^{22}$ ), todas as vasilhas têm de ser preparadas para belamente acolher a força movente, e teremos de expor tudo que há de material para o lustro dos céus, de modo que estes teçam na trama das coisas os fios de ouro que acabam o festivamente desenho.

O mito trágico pode ser compreendido somente como uma trama de imagens (Verbildlichung) da sabedoria dionisíaca com os meios artísticos apolíneos [...] Ste. 127. Anteriormente ao mito trágico já deve existir aquela ação 'musical' cujo palco/cenário é o espaço no qual os espectadores se encontram, levados pelo sentimento de união e unidade (Einheit) ${ }^{23}$. Tal como o coro da antiguidade que apresentava suas danças ditirâmbicas no espaço elevado [do teatro], assim deve o sentimento começar a dançar

\footnotetext{
${ }^{22} \mathrm{~A}$ concepção rilkeana do ritmo e da melodia como forças elementares do poeta lírico apóia-se não somente nas ideias de Nietzsche, mas também em Maeterlinck. Para ilustrar o lado performático da teoria rítmica do poeta, Horst Nalewski relata a anedota da estada de Rilke na casa de Heinrich Vogeler; Rilke tanto acompanhava suas recitações com gestos e batidas que a governanta escutava, perplexa, os passos movimentos rítmicos de Rilke no quarto acima. (KA, IV, 839). - Mas por mais que Rilke apostasse na força rítmica, ele começou mais tarde a desconfiar do modo associativo e deslizante que ameaça a poesia e a criação em geral com sua monotonia e falta de rigor do pensamento. "Eu poderia ter continuado indefinidamente a fazer tais versos, [...] e depois, o que?"[carta a Katharina Kippenberg] (RILKE, 1942, p. 164).

23Este ideal de uma sensibilidade compartilhada (sensus communis - condição de possibilidade da comunidade livre) opõe-se ao espectro da massa histérica ou fanática (cuja unidade se baseia em necessidades sociais e carências psicológicas).
} 
ROSENFIELD, Kathrin (2016) Ritmo e música no pensamento de poetas e filósofos: de Hölderlin a Rilke e Heidegger. Per Musi. Ed. por Fausto Borém e Lia Tomás. Belo Horizonte: UFMG, n.35, p.15-45.

na alma elevada do espectador único e uno que se compõe, como por milagre, de centenas de seres humanos quando observa o jogo teatral. Tenho o nítido sentimento de que o coro deve ser instaurado no espectador, não no espectador singular, mas no estar-junto (Gemeinsamkeit) surpreendentemente festivo de todos, comunidade esta que deve criar-se por um prólogo e prelúdio (Vorspiel) antes do drama. Somente quando um único homem atemporal, não quinhentos homens de hoje, se sentam diante do palco aguardando [o drama desta re-união], terá algum sentido o levantar da cortina ${ }^{24}$.

Se aplicássemos estes preceitos ao drama [moderno], estariam restabelecidos também aqui os direitos da melodia de fundo. Perseguindo este intuito, Eurípides tão somente seguiu seu sentimento seguro e certeiro (gutes Gefühl), quando colocou no prólogo a narrativa do conteúdo de suas peças, pois este conteúdo já não foi mais tirado dos mitos antigos ${ }^{25}$. No drama novo/moderno, o mesmo teria de acontecer neste prólogo que tenho em mente (mesmo quando se trata de um material mítico realmente conhecido), pois os mitos não são mais tão vivos nos dias de hoje e mais suscitam lembranças escolares mortas do que verdadeiras relações poéticas. 0 prólogo teria de 1) unir os espectadores, fundindo-os e construindo aquele palco imaginário que moverá seus sentimentos, e, 2) contar para o público, durante o processo de sua fusão, a trama da ação iminente, de forma que a força que, de outro modo, se dissiparia em tensão e curiosidade, ficaria guardada para uma verdadeira participação. -

Aquela morte da tragédia foi ao mesmo tempo a morte do mito. Até então, os gregos tinham tão somente a possibilidade de vincular tudo o que viviam e experimentavam diretamente com seus mitos, mais: de compreendê-lo tão somente através deste vínculo.

\footnotetext{
${ }^{24} \mathrm{~A}$ nostalgia da unidade de todas as coisas - de seres humanos de diferentes classes e ordens, mas também de animais e plantas, coisas fabricadas ou minerais - é o motor dos rituais dionisíacos, dos mitos e lendas. Seus ecos ressurgem nas lembranças infantis, e, em particular, nas melodias e narrativas compartilhadas que constituem, para Rilke (como para Hölderlin), o lastro unificador da sociabilidade e da cultura.

${ }^{25}$ Embora os enredos dos mitos trágicos de Eurípedes possam ser novos, este último dos três grandes trágicos antecipa no prólogo a "história" e, satisfazendo a curiosidade, libera a atenção do público para a ação poética do drama. Brecht retoma esta ideia e a combina com o estranhamento para suscitar considerações críticas do público.
} 
À propósito Ste. 135. Na tragédia ática antiga, tudo o que é contado ainda estava vinculado com os velhos mitos conhecidos; e como estes eram as únicas imagensparábolas pelas quais fluíam e jorravam os tons sempre novos como forças e cores diversas, não havia como sobrevalorizar a "matéria" do enredo. Somente com o aumento dos pretextos ocorreu em todas as artes esta sobrevalorização, simplesmente porque estes enredos-pretextos não eram mais, como os mitos, conteúdos familiares, [porém] suscitavam interesse pela novidade do material ${ }^{26}$. Assim, o olhar perdeu cada vez mais a visão da única coisa importante, do fundo [musical, rítmico] , até perder-se de vez nas confusões da ação do enredo, esgotando-se neles. A pintura foi a primeira a encontrar o caminho de volta desta errância, pois ela gosta de se voltar, sempre de novo para os motivos tradicionais bem conhecidos e tem o sentido vivo e natural da vantagem inerente ao fato que o espectador não precisa começar a debater-se com o conteúdo da imagem.
Atrás de mim há coros sombrios
Florestas ruflam e mares chiam;
E dos ombros solta-se o peso,
Quando por trás, no fundo
Ouço, mais amplo que o meu,
Um hálito que envolve o mundo.
E sei que posso confiar,
Que minhas mãos não me enganam
Se delas novas formas emanam
E que o peso todo aturam
Para poder, quando respiram,
No peito fundo o ar tragar.
(18 de março 1900)

Música, suavizada pela ação do enredo: eis o que expressaria a essência do drama de modo mais sucinto; e num sentido mais amplo poderíamos dizer: a aplicação, no e para o nosso mundo, da força livre de Deus que não foi concebida para nós ${ }^{27}$. Ao gasto aparente desta força a nosso favor corresponde a aparente perfeição da criação do

\footnotetext{
${ }^{26} \mathrm{Em}$ outras palavras: em vez da sensibilidade e do pensamento estarem abertos ao fundo rítmico (inquietante e maravilhoso) da existência, a consciência adquire um foco mais estreito; assim, ela se desloca para determinado foco (político, social, familiar, histórico, artístico etc.) e adquire a forma do conhecimento e do domínio, que viabilizam a reflexão e a ação dos indivíduos e das comunidades.

${ }^{27}$ Rilke afirma aqui sua visão do mundo des-centrado. Desde Hölderlin e Kleist, o ser humano não é mais o centro, nem o ponto de referência único do universo. A razão de ser da arte é da música é precisamente de nos dar acesso a outras dimensões da existência e do ser.
} 
ROSENFIELD, Kathrin (2016) Ritmo e música no pensamento de poetas e filósofos: de Hölderlin a Rilke e Heidegger. Per Musi. Ed. por Fausto Borém e Lia Tomás. Belo Horizonte: UFMG, n.35, p.15-45.

mundo através da beleza - a arte é, portanto, o complemento da imagem de Deus, que expressa o mundo real apenas parcialmente.

Com a força da potência dionisíaca, isto é, do elemento que flui ritmicamente e é hostil às formas, forçosamente crescem também, enquanto resistência, a beleza e o rigor da forma. Aquele povo cujas pulsões dionisíacas são as mais veementes, rugindo com mais força, precisa ter o maior rigor na formação pessoal e na de suas obras, e isto, simplesmente para poder subsistir. 0 júbilo desatado da comoção íntima intensifica a tranquilidade flexível da forma que ele move.

Parece-me que foi o acaso Wagner o responsável por Nietzsche de imediato debruçarse sobre esta oportunidade próxima (próxima demais!), aplicando a ela seus conhecimentos e esperanças que tão pouco combinam com a essência alemã; isto prejudica grandemente o último terço do livro. Este dano é maior do que o uso da terminologia de Kant e Schopenhauer. Se, em particular, a concepção Schopenhaueriana da música contribuiu muito para adiantar as intenções de Nietzsche, a aplicação imediata de todo o material recém-descoberto às criações de Wagner criam uma atmosfera decepcionante; na verdade, não queremos que todas estas coisas elevadas e prometidas se realizem de imediato, e sobre tudo acreditamos que o redator do livro teria a capacidade (enquanto poeta) para tentar de "ressuscitar Dionysos".

\section{6- Anexo2 - Rainer Maria Rilke: "Com relação às coisas russas" 28}

Não seria o elemento dionisíaco aquilo que move os cortejos (chorowod) dos russos? Enquanto as cantorias dos Sentados - figuras dos antigos cantos heroicos representam os corpos de forma pesada e tangível, todas as fronteiras estilhaçam sob

${ }^{28}$ Tradução de Kathrin Rosenfield. 
ROSENFIELD, Kathrin (2016) Ritmo e música no pensamento de poetas e filósofos: de Hölderlin a Rilke e Heidegger. Per Musi. Ed. por Fausto Borém e Lia Tomás. Belo Horizonte: UFMG, n.35, p.15-45.

do impacto daquelas canções que irrompem acelerando e engolindo os giros dos cortejos circulares.

E não seria o mito russo o único que ainda tem proximidade suficiente com as massas para poder ser usado mais uma vez como parábola da vida livre do som? - entre nós, procuraríamos em vão figuras que possam ser coreutas, ao passo que é fácil imaginar um grupo demujiks apresentando num palco (Vorbühne) cantorias dançantes que devem suscitar aquela visão na qual o verdadeiro drama se apresenta. 0 que o sátiro expressava através de sua proximidade e sabedoria do mundo concreto (Weltnähe und Weltweisheit), aquilo que perdura, é o que também viria à tona no caso destes camponeses e de sua visão. De modo análogo, o drama seria visualmente forte e mesmo assim não pesaria demais sobre o sentimento.

Chama atenção que, em todos os efeitos mencionados, podemos sempre substituir no lugar do termo "música" aquela outra coisa que não é música, mas que se expressa do modo mais puro apenas pela música. 0 poeta lírico não precisa da música para criar, mas apenas daquela sensação rítmica que já não precisaria mais do poema se pudesse antes ganhar voz na música. E não queria a música em geral dizer aquela primeira, obscura causa da música, e com isto a causa de toda a arte? Força livre e movente, excesso de Deus? Também a pintura e a escultura só têm o alvo de interpretar aquela "música", de gastá-la em imagens. E então a música poderia ser algo como a traição daqueles ritmos, a primeira forma de sua aplicação, ainda não aplicada às coisas do mundo, mas aos sentimentos e sensações, a nós. A isto seguiria a lírica que nos vincula docemente com o mundo ao falar de nossos sentimentos como se fossem coisas do mundo; e de dentro da lírica desenvolve-se, por intermédio das artes plásticas (que já tratam de um modo simbólico das coisas do mundo) surge o drama, a interpretação mais imagética e, por isto, a mais perecível dos ritmos ocultos; esta derradeira interpretação, no entanto, visa despertar nos espectadores aquela causa primária da arte, ela destrói a individualidade nos espectadores singulares e cria uma unidade entre centenas, isto é, um instrumento para aqueles ruídos de fundo dionisíacos. E assim fecha-se aqui o círculo. Emergindo da multidão violentamente unificada pela embriaguez do olhar, solta-se um ser singular graças a sua força sombria, isolando sua figura e desperdiçando nos sons de uma flauta o deus que possui a multidão abalada. 
O originário é o bater das ondas do ilimitado e sua mais perfeita e completa expressão: música. Em quase toda sua amplidão a tela de fundo movimentada ganha voz na música, - ao passo que no drama, que é sua derradeira aplicação, encontra seu lugar apenas uma parte pequena desta tela de fundo que se incorpora nas figuras dramáticas esguias; mas esta parcela da tela de fundo tem aquele efeito de transformar os espectadores em uma coisa relativamente ilimitada, surtindo, assim, um palco momentâneo daquela maré originária (Wellenschlag).

Quanto maior a multidão que é unida pela tragédia, maior será também a cena do originário e tanto mais importante seu efeito. 0 drama deve, consequentemente, unir, sintetizar, na mesma medida em que expressões artísticas que estão mais próximas do ritmo originário, (música, lírica) devem tornar solitário[o artista e o espectador] . Quanto mais ampla e completa a tela de fundo [...]

\section{7- Anexo 3 - Rainer Maria Rilke, Parágrafos III-XIV de: “A Melodia das coisas" 29}

III. Lembrei: observando, me ocorreu que ainda costumamos pintar seres humanos contra um fundo de ouro. Como os Primitivos. Eles se erguem diante de algo indeterminado. Às vezes diante de um fundo de ouro, às vezes também um cinzento. Às vezes na luz, e frequentemente com um breu impenetrável por trás.

IV. Isto é compreensível. Para reconhecer os seres humanos era necessário isolá-los. Mas depois de uma experiência prolongada cabe recolocar estas contemplações

\footnotetext{
${ }^{29}$ Tradução de Kathrin Rosenfield.
} 
isoladas de novo numa relação, e de acompanhar com um olhar amadurecido seus gestos amplos.

V. Compare uma vez um quadro com fundo de ouro do Trecento (século XIV) com uma das numerosas composições mais tardias dos mestres italianos, nos quais as figuras se encontram para uma Santa Conversazione diante da tela de fundo de uma paisagem luminosa no ar luzente de úmbria. 0 fundo de ouro isola cada uma das figuras, a paisagem atrás deles brilha como uma alma comum, de dentro da qual eles bebem seus sorrisos e seu amor.

XII. De ilha em ilha não há outra possibilidade: saltos perigosos nos quais arriscamos mais do que os pés. Um constante pular para lá e para cá se cria, com acasos e ridículos; pois acontece que dois seres saltam um para o outro, ao mesmo tempo, de forma que só se encontram no ar, e depois desta troca penosa terminam tão afastados - um longe do outro - como antes.

XIII. Isto não é muito surpreendente; pois, na verdade, as pontes que levam para a união e pelas quais se anda com passos belos e festivos não estão dentro de nós, mas atrás de nós, bem como o vemos nas paisagens do Fra Bartholomeo ou de Leonardo. A bem da verdade, a vida se aguça nas personalidades singulares. De pico para pico, no entanto, a senda passa por vales largos.

XIV. Quando dois ou três pessoas se juntam, não estão por isto unidos e juntos. São como marionetes cujos fios estão em mãos diversas. Somente quando uma mão guia todos, há algo comum que se estende sobre eles, algo que os leva a se inclinarem um diante do outro ou a se bater. E também as forças do homem estão, onde terminam os fios, numa mão que sustenta e reina. ${ }^{30}$

\footnotetext{
${ }^{30}$ Este parágrafo, em particular, já antecipa a ideia do movimento musical e rítmico que guia e move a representação artística (e sua recepção pelos espectadores). Para Nietzsche, o coro trágico é a figura do sonhador coletivo que permite aos espectadores entrar no movimento rítmico do drama (e da vida). Em vez de se fixar nos detalhes isolados do enredo, pensando na significação de cada personagem ou palavra, o coro permite perceber seu movimento: como uma grande onda, a música reconfigura os conteúdos tradicionais.
} 


\section{Referências}

1. BOHRER, K. H. (1998) Die Grenzen des Aesthetischen.München: Hanser.

2. (2000) Sprachen der Ironie, Sprachen des Ernstes. Frankfurt, Suhrkamp.

3. CAMPOS, A. (2001) Coisas e Anjos de Rilke. Perspectiva,

4. CAMPOS, H. (1969) Poesia de Vanguarda Alemã e Brasileira. In: A arte no horizonte do provável, São Paulo, Perspectiva.

5. HEGEL, G. F. W. (1973) Phänomenologie dês Geistes (Ph): KommentarzurRezeptionsgeschichtevon Gerhard Göhler. Frankfurt am Main: Ullstein.

6. ___ (2002) A fenomenologia do espírito (FE). Trad. Paulo Meneses e KarlHeinszEfken. Petrópolis: Vozes.

$7 .+\ldots$ (20 vol.), Frankfurt, Suhrkamp.

8. HEIDEGGER, M. (1994) Vom Ereignis, Beitraege zur Philosophie, Gesamtausgabe, Bd. 65, Frankfurt a. M.,S. 17.

9. ___ (2006) Sein und Zeit. Niemeyer, Tübingen.

10. ___ (1979) Sein und Zeit, Tübingen, Max Niemeyer.

11.___. (2001) Ser e Tempo, Trad. Marcia de Sá Cavalcante, Petropolis, Vozes.

12. ___. Einführung in die Metaphysik, Tübingen, Max Niemeyer, 1966.

13___. Beiträge zur Philosophie (Vom Ereignis). In Gesamtausgabe, Frankfurt am Main,1994, Bd. 65.

14. HÖLDERLIN, F. (1994) Anmerkungenzum Ödipus und zur Antigonä. In: Friedrich Hölderlin, Sämtliche Werke und Briefe, 3 vols., Frankfurt am Main, Deutscher Klassiker Verlag, 1994, (DKV, vol. 2, pp. 849-859; 913-921).

15. MAN, P. (1972) Introduction. In: RILKE, R. M. Oeuvres - Poésie (vol. 2).

16. NIETZSCHE, F. (1982). Die Geburt der Tragödie, in Werke, 3 vols., Darmstadt (vol. 1).

17. RILKE, R. M. (1996) Werke Kommentierte Ausgabe in vier Bänden (KA). Frankfurt amMain, Insel Verlag. 
18. ___ (1996) “ < Marginalia em torno de Friedrich Nietzsche: 'O Nascimento da Tragédia>” 1900. Texto traduzido do ensaio 'Marginalien zu Friedrich Nietzsche', in: Rilke, Werke. KommentierteAusgabe in vierBänden, Bd. 4, Schriften, Frankfurt am Main, Insel Verlag, pp. 161-173.

19. (1942) Ein Beitrag. Leipzig.

20. . (1972) Oeuvres - Poésie (vol. 2). Introduction de Paul de Man, Paris, Seuil.

\section{SARAIVA, A. (1984) Para a História da Leitura de Rilke em Portugal e no}

Brasil. Edições Arvore, Porto.

22. SCHOPENHAUER, A. (1983) Sämtliche Werk, 5 vols.Frankfurt am Main, Suhrkamp.

23. . (2014) Die Welt alsWille und Vorstellung" (WWV).

Disponívelem<http://www.zeno.org/Philosophie/M/Schopenhauer,+Arthur/Di e+Welt+als+Wille+und+Vorstellung>. Acesso em: abril de 2014.

Nota sobre a autora

Kathrin Rosenfield, Professora Titular no Dpto. de Filosofia da UFRGS, possui graduação em Letras pela Université de Paris III (Sorbonne-Nouvelle) (1980), mestrado em Antropologia Histórica pela École des Hautes Études en Sciences Sociales (1981) e doutorado em Ciência da Literatura pela Universidade de Salzburg (1984). Pós Doutorado na École Normale Supérieure (Ulm-Paris) sobre Hölderlin e Sófocles; e Pós Doutorado na University of Massachusetts, Amherst sobre tradução e crítica da obra de Robert Musil e Releitura da versão hölderliniana de Édipo Rei de Sófocles. Atualmente é professora associada da Universidade Federal do Rio Grande do Sul. Tem experiência nas áreas de Filosofia e Literatura, com ênfase em Teoria Literária, atuando principalmente nos seguintes temas: Estética, Filosofia e Literatura, Literaturas Brasileira, Literaturas Germanica e Austriaca, Literatura Anglo-Saxã, Psicanálise, Arte. 